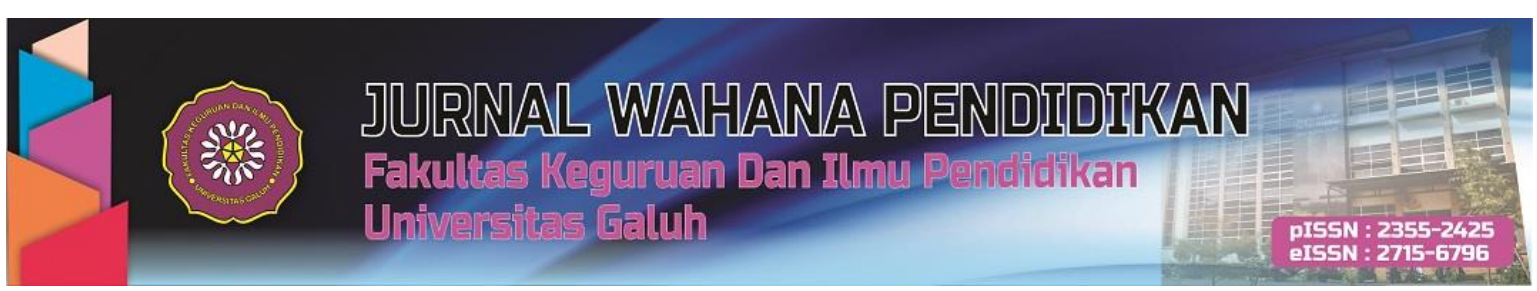

https://jurnal.unigal.ac.id/index.php/jwp

\title{
MENINGKATKAN HASIL BELAJAR IPA SISWA MELALUI PENERAPAN METODE PEMBELAJARAN DISCOVERY TERBIMBING DI KELAS VI SD NEGERI 2 TANJUNG KOTA TASIKMALAYA
}

\author{
Rokayah \\ SDN 2 Tanjung, Jl. Air Tanjung Gununggede Kec. Kawalu, Kota Tasikmalaya, Jawa Barat, Indonesia \\ Email: rokayahya34@gmail.com
}

\begin{abstract}
Based on the results of observations to grade VI students of SD Negeri 2 Tanjung Kota Tasikmalaya, most of the students had scores that had not yet reached the KKM. Factors that are considered to be the trigger for the low learning outcomes of students' science learning include students who pay less attention to learning. This happens because students consider science learning in the classroom less challenging and boring so that students are less interested in paying attention to science lessons. Therefore it is necessary to make efforts to improve student learning outcomes through the application of appropriate learning methods. This study aims to improve the science learning outcomes of grade VI SD Negeri 2 Tanjung Kota Tasikmalaya using guided discovery learning methods. This type of research is a classroom action research using the Kemmis and Taggart model. The subjects of this study were 41 students of grade $\mathrm{VI}$. This research was conducted in two cycles of action. In each cycle, there are planning, implementation, observation and reflection activities. The instruments used were observation sheets and test. The results of the first cycle research showed that the percentage of students whose grades were above the KKM had only reached $70.73 \%$, so they still could not reach the criteria for research success. In the second cycle, the percentage of learning completeness increased to $85.37 \%$. The results of these studies indicate that the application of the guided discovey method can improve science learning outcomes.
\end{abstract}

Keywords: learning methods, guided discovery, learning outcomes

\section{ABSTRAK}

Berdasarkan hasil observasi kepada siswa kelas VI SD Negeri 2 Tanjung Kota Tasikmalaya, sebagaian besar siswa memiliki nilai masih belum mencapai KKM. Faktor yang dianggap menjadi pemicu rendahnya hasil belajar IPA siswa, diantaranya siswa kurang memerhatikan pembelajaran. Terjadinya hal ini dikarenakan siswa menganggap pembelajaran IPA di kelas kurang menantang dan membosankan sehingga siswa kurang menaruh minat untuk memperhatikan pelajaran. Oleh karena itu perlu adanya upaya untuk meningkatkan hasil belajar siswa melalui penerapan metode pembelajaran yang tepat. Tujuan penelitian ini untuk meningkatkan hasil belajar IPA siswa kelas VI SD Negeri 2 Tanjung Kota Tasikmalaya menggunakan metode pembelajaran discovery terbimbing. Jenis penelitian ini berupa penelitian tindakan kelas (PTK) menggunakan model penelitian tindakan dari Kemmis dan Taggart. Subjek penelitian ini adalah siswa kelas VI yang berjumlah 41 orang siswa. Pelaksanaan penelitian ini dalam dua siklus tindakan. Pada masingmasing siklus ada kegiatan perencanaan, pelaksanaan, observasi, dan refleksi. Instrumen dengan menggunakan lembar observasi dan tes. Hasil penelitian siklus I memperlihatkan persentase siswa yang nilainya di atas KKM baru mencapai $70,73 \%$, sehingga masih belum dapat mencapai kriteria keberhasilan penelitian. Pada siklus II persentase ketuntasan belajar meningkat menjadi $85,37 \%$. Hasil penelitian tersebut menunjukkan bahwa penerapan metode discovery terbimbing mampu meningkatkan hasil belajar IPA.

Kata Kunci: metode pembelajaran, discovery terbimbing, hasil belajar IPA

Cara sitasi:

Rokayah. (2020). Meningkatkan Hasil Belajar IPA Siswa Melalui Penerapan Metode Pembelajaran Discovery Terbimbing di Kelas VI SD Negeri 2 Tanjung Kota Tasikmalaya. Jurnal Wahana Pendidikan, 8 (1), 53- 60. 


\section{PENDAHULUAN}

IPA (IImu Pengetahuan Alam) adalah sebuah mata pelajaran wajib di Sekolah Dasar. Fokus dari pembelajaran IPA ialah pada pemberian pengalaman langsung. Pembelajaran IPA merupakan sebuah sarana untuk mengembangkan siswa dalam berpikir ilmiah dan rasional melalui eksperimentasi, penyusunan teori, penyimpulan, observasi, dan lainnya yang saling terkait antar setiap caranya (Aly dan Rahma, 1998). Maka dari itu, IPA memiliki kaitan yang sangat luas dengan kehidupan individu.

Berdasarkan hasil observasi awal kepada siswa kelas VI SD Negeri 2 Tanjung Kota Tasikmalaya, KKM (Kriteria Ketuntatasan Minimal) mata pelajaran IPA adalah 70. Dari 41 orang siswa, sebagaian besar siswa memiliki nilai masih belum mencapai KKM atau 43,90\%. Kondisi tersebut menunjukkan bahwa lebih dari 50\% nilai IPA belum sesuai dengan KKM.

Faktor-faktor yang dianggap menjadi pemicu rendahnya hasil belajar IPA siswa, diantaranya siswa kurang memperhatikan pembelajaran. Terjadinya hal ini dikarenakan siswa menganggap pembelajaran IPA di kelas kurang menantang dan membosankan sehingga siswa kurang menaruh minat untuk memperhatikan pelajaran. Pada pembelajaran IPA selama ini sering menerapkan pendekatan pembelajaran ekspositori, yakni pembelajaran berbentuk pemberian informasi verbal dari penjelasan guru serta buku. Siswa sebatas mendapat informasi lewat aktivitas mencatat, membaca, serta mendengarkan.

Pendekatan pembelajaran ekspositori yakni pembelajaran teacher centered (terpusat pada guru), guru belum memerankan fungsinya secara maksimal sebagai figur sentral, baik sebagai dinamisator, fasilitator, organisator, ataupun sebagai pelayan untuk siswa. Akibat yang ditimbulkan adalah monotonnya suasana pembelajaran, siswa kurang aktif, lekas bosan, serta merasa jenuh. Oleh karenanya metode ekspositori bisa dibilang kurang baik apabila diaplikasikan pada pembelajaran IPA yang memerlukan praktikum, walaupun juga metode ekspositori masih relevan untuk diaplikasikan pada suatu materi. Metode ekspositori lebih efektif dan efisien untuk menyampaikan informasi dan pengertian (Darmawani, 2018).

Mayoritas sumber belajar yang dipakai sifatnya tekstual berbentuk buku dan gambar, tidak berkegiatan praktik seperti yang diharuskan pada pembelajaran IPA. Pada pendekatan pembelajaran ekspositori peran siswa kurang aktif, sehingga dalam kegiatan belajar mengajar, teramat jarang ditemukan siswa bertanya dan menjawab pertanyaan guru. Siswa lebih cenderung asyik menulis serta mencatat materi di papan tulis, sehingga penjelasan guru kurang diperhatikan. Kerap ditemukan juga siswa mengganggu sesama siswa serta membuat gaduh di kelas.

Rasa bosan siswa selama belajar di kelas umumnya dikarenakan ketidaksesuaian pendekatan pembelajaran dengan tujuan pembelajaran IPA. Diperlukan upaya untuk melibatkan siswa dalam proses menemukan gejala alam di sekitarnya, sehingga siswa akan merasa dapat menemukan pemecahan permasalahnya sendiri. Salah satu metode pembelajaran yang dapat membangkitkan minat belajar siswa serta yang paling sesuai dengan tujuan pembelajaran IPA ialah metode discovery atau penemuan. Siswa akan dibuat tertantang serta bertindak aktif untuk menemukan konsep serta memperoleh pengalaman sendiri lewat aktivitas percobaan (Marselus, et.al, 2018).

Metode discovery ialah metode pembelajaran dimana bisa menumbuhkan sensitifitas pola pikir siswa secara inovatif, kritis, serta aktif. Maka dari hal tersebut, idealnya pembelajaran IPA untuk tingkatan siswa SD yakni berfokus kepada pengalaman secara langsung. Tujuannya ialah supaya bisa menstimulasi sensitifitas daya pikir siswa akan gejala alam yang terjadi, memicu motivasi pola pikir aktif siswa dalam memecahkan serta mengkritisi permasalahan yang ada secara mengelompok terkait fenomena alam yang terjadi (Fauziana, 2019).

Siswa bisa dengan mudah menguasai serta memahami materi IPA sebab bekerjasama serta terlibat langsung. Uraian tersebut selaras dengan hasil penelitian terdahulu yang membuktikan, hasil belajar siswa melalui penerapan metode pembelajaran discovery cenderung lebih baik dibanding penerapan metode pembelajaran konvensional (Sutiyah, 2015). Berdasarkan latar 
belakang tersebut tujuan penelitian ini adalah meningkatkan hasil belajar IPA siswa kelas VI SD Negeri 2 Tanjung Kota Tasikmalaya menggunakan metode pembelajaran discovery terbimbing.

\section{METODE PENELITIAN}

Metode penelitian ini berupa PTK (Penelitian Tindakan Kelas). PTK ini telah dijalankan terhadap siswa kelas VI SD Negeri 2 Tanjung Kota Tasikmalaya dengan siswa sejumlah 41 orang. Pelaksanaan penelitian tindakan kelas ini sebanyak dua siklus dimana setiap siklusnya dilaksanakan dua kali pertemuan. Pelaksanaan siklus I pada tanggal 17 hingga 19 September 2018 sementara pelaksanaan siklus II pada tanggal 8 hingga 10 Oktober 2018.

Fokus dari penelitian ini yakni pada penerapan metode pembelajaran discovery terbimbing untuk meningkatkan hasil belajar kognitif siswa. Instrumen penelitian menggunakan tes dan lembar observasi. Prosedur Penelitian tindakan kelas ini meliputi: a)Menetapkan fokus masalah; b)Merencanakan tindakan; c)Melaksanakan tindakan diikuti dengan observasi serta interpretasi, d)Analisa dan refleksi; dan e)Merencanakan tindak lanjutan apabila dibutuhkan (Arikunto dan Suhardjono, 2006). Penelitian tindakan ini langkah-langkahnya mengadaptasi PTK Model Kemmis dan Taggart yakni seperti pada Gambar 1.

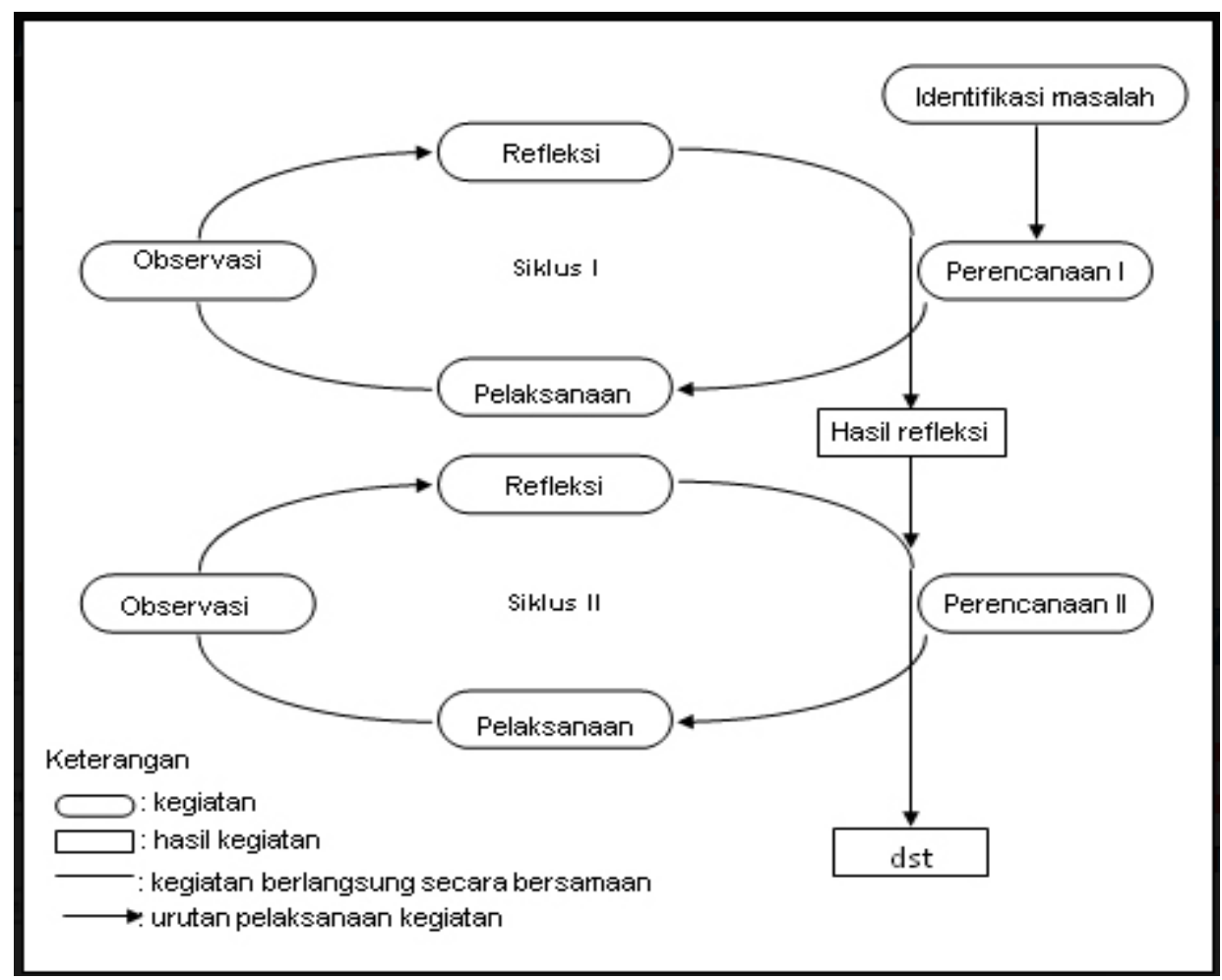

Gambar 1. Bagan PTK Model Kemmis dan Taggart Arikunto (2006)

Pelaksanaan penelitian ini dilaksanakan sebanyak 2 siklus. Tiap siklus pembelajaran dijabarkan sebagai berikut:

1. Planning (perencanaan)

Pada tahap ini dilaksanakan asesmen terhadap metode pembelajaran IPA. Berdasarkan pengalaman selama mengajar didapat sebuah masalah terkait kegiatan pembelajaran IPA, dimana peneliti lebih dominan memakai metode pembelajaran verbal, oleh karenanya aspek pengalaman siswa terkait penemuan konsep IPA kurang diperhatikan, dan memicu rendahnya hasil belajar IPA.

Berdasar permasalahan ini, maka peneliti dalam tahap perencanaan menyusun rencana yakni: a) penetapan materi pelajaran IPA memanfaatkan pendekatan metode pembelajaran discovery terbimbing; b) penetapan tujuan pembelajaran; c) menyusun tahapan pembelajaran IPA 
berbentuk RPP (Rencana Pelaksanaan Pembelajaran); dan d) menyusun instrument untuk dijadikan acuan observasi dalam melaksanakan pembelajaran IPA.

2. Acting (tindakan)

Tindakan sebagai pelaksanaan dari kegiatan yang sudah direncanakan. Sifat perencanaannya harus terbuka serta flexible terhadap berbagai perubahan dalam pelaksanaan tindakannya. Apabila sebuah tindakan sifatnya dinamis serta tidak tetap dimana membutuhkan kecepatan keputusan terkait yang perlu dilaksanakan. Perencanaan tindakan dengan mengkaji materi perkembangbiakan makhluk hidup lewat metode pembelajaran discovery terbimbing. Guru selama proses belajar mengajar mengaplikasikan tahapan pembelajaran discovery terbimbing dengan berpedoman terhadap skenario pembelajaran yang disusun mengikuti sintak pembelajaran discovery terbimbing yaitu: a) observasi untuk menemukan masalah; b) merumuskan masalah, c) mengajukan hipotesis; d) merencanakan pemecahan masalah (melalui eksperimen atau cara lain), e) melaksanakan eksperimen (atau cara pemecahan masalah yang lain), f) melakukan pengamatan dan pengumpulan data; dan g) analisis data (Hamdani, 2011).

3. Observing (observasi atau pengamatan)

Pengamatan atau observasi ialah cara mengamati tindakan yang dilakukan, yakni metode pembelajaran discovery terbimbing untuk pembelajaran materi makhluk hidup. Pelaksanaan observasi ini berlangsung guna mendokumentasikan pelaksanaan pengaruh tindakan yang memiliki orientasi ke masa depan serta menjadi landasan untuk refleksi yang lebih kritis. Kendala tindakan, situasi tempat pelaksanaan tindakan, pengaruh tindakan yang tidak disengaja maupun disengaja, serta proses tindakan, seluruhnya dilakukan pencatatan secara terbuka dan fleksibel dalam observasi yang terencana. Terkait tahapan ini, diadakan pengamatan pada proses belajar mengajar memanfaatkan metode pembelajaran discovery terbimbing dimana pelaksanaannya memakai format pengamatan, mencatat hasil pengamatan terkait hasil serta proses pembelajaran, melakukan dokumentasi terkait berbagai hasil penugasan dan latihan siswa.

4. Reflecting (perefleksian)

Berdasarkan pada hasil pengamatan, peneliti melakukan refleksi pada hasil serta proses pembelajaran yang dicapai dalam tindakan ini. Pelaksanaan refleksi ini melalui: a) mengevaluasi tindakan yang sudah dijalankan dimana mencakup evaluasi waktu dan jumlah setiap tindakan, serta hasil belajar; b) mengkaji LKS dan hasil evaluasi; dan c) memperbaiki tindakan yang dilaksanakan dengan menyesuaikan hasil evaluasi untuk dipakai dalam siklus selanjutnya

Berdasarkan pada refleksi yang sudah dijalankan, peneliti bisa mengetahui berbagai hal yang hendak dilaksanakan pada siklus selanjutnya. Hal ini dilakukan agar mencapai hasil pembelajaran yang diharapkan serta menunjang terhadap peningkatan kemampuan siswa dalam memahami konsep mengenai makhluk hidup lewat metode pembelajaran discovery terbimbing. Keputusan melanjutkan atau menghentikan siklus disesuaikan dengan hasil pembelajaran. Dihentikan apabila pembelajarannya telah sesuai dengan rencana dan sudah dapat meningkatkan wawasan siswa pada konsep mengenai perkembangbiakan makhluk hidup. Tolak ukur seberapa berhasilnya tindakan dalam penelitian tindakan kelas ini ditunjukkan dengan meningkatnya nilai hasil belajar siswa yakni persentase keseluruhan siswa yang tuntas minimum $80 \%$ serta nilai rata-rata kelas mencapai KKM (70).

\section{HASIL DAN PEMBAHASAN}

Ketika observasi, peneliti mendapati bahwa pelaksanaan pembelajaran IPA cenderung kurang menarik perhatian siswa. Guru menerangkan materi memanfaatkan pendekatan pembelajaran ekspositori, yakni pembelajaran berbentuk informasi verbal dimana didapat dari penjelasan peneliti dan buku. Siswa sebatas mendapat informasi lewat kegiatan mencatat, membaca, dan mendengarkan. Mayoritas sumber belajar yang dipakai bersifat tekstual, yakni bahan ajar cetak yang secara sistematis dirancang guna mewujudkan tujuan pembelajaran semacam buku dan gambaran. Sehingga, tidak sedikit siswa yang kurang antusias dalam proses belajar mengajar. 
Berdasarkan hasil test pra tindakan diketahu bahwa siswa yang sudah memenuhi KKM baru $43,90 \%$ dan nilai rata-rata kelas 62,02 . Hasil ini memperlihatkan bahwa masih rendahnya hasil belajar IPA siswa pada materi membandingkan sifat kemampuan menghantarkan panas dari berbagai benda sehingga dibutuhkan segera tindakan perbaikan oleh peneliti guna meningkatkan hasil belajar siswa.

\section{Siklus I}

Pada tindakan siklus I dengan bahan praktikum yang telah masing-masing kelompok bawa, kemudian peneliti membagi tempat duduk siswa sesuai kelompoknya. Siswa melakukan percobaan tentang perkembangbiakan pada tumbuhan serta memakai LKS yang telah dipersiapkan peneliti. Siswa menjalankan praktikum melalui bimbingan peneliti dengan menerapkan langkah-langkah metode discovery terbimbing. Sesudah pelaksanaan praktikum selesai, masing-masing kelompok menyimpulkan. Sebelum berakhirnya pelajaran, diadakan posttest terkait materi yang sudah siswa pelajari.

Berdasarkan hasil pengolahan data, ada peningkatan nilai rata-rata kelas pembelajaran siklus I jika dibandingkan dengan nilai rata-rata kelas pra tindakan. Perbandingan hasil belajar tersebut dijabarkan pada Tabel 1.

Tabel 1.

Perbandingan Hasil Belajar IPA Siswa Pada Pra Tindakan dan Siklus I

\begin{tabular}{clll}
\hline No & \multicolumn{1}{c}{ Indikator } & \multicolumn{1}{c}{ Pra Tindakan } & \multicolumn{1}{c}{ Siklus I } \\
\hline 1 & Nilai rata-rata & 62,02 & 71,83 \\
2 & Jumlah Siswa tuntas & 18 orang & 29 orang \\
3 & Jumlah siswa tidak tuntas & 23 orang & 12 orang \\
4 & Ketuntasan Belajar & $43,90 \%$ & $70,73 \%$ \\
\hline
\end{tabular}

Berdasarkan data pada Tabel 1, nilai rata-rata siklus I meningkat dibandingkan pra tindakan yakni menjadi 71,83 dari 62,02 , artinya adanya peningkatan sebesar 9,80 . Persentase siswa pada siklus I yang telah mencapai KKM sejumlah 29 orang atau sebesar $70,73 \%$ meningkat sebesar $26,83 \%$ dari ketuntasan belajar pratindakan yaitu sebesar $43,90 \%$.

Hasil belajar IPA siswa pada siklus I mengalami peningkatan dikarenakan metode pembelajaran discovery terbimbing yang dipakai dapat membimbing serta memfasilitasi siswa dalam membedakan perkembangbiakan vegetatif dan perkembangbiakan generatif pada tumbuhan lewat kegiatan praktikum sehingga siswa bisa mencari konsepnya sendiri. Penelitian siklus I menghasilkan, persentase siswa dengan nilai melebihi KKM baru sejumlah 70,73\%. Artinya kriteria keberhasilan penelitian belum dicapai sehingga dilanjutkan ke tindakan siklus II.

\section{Siklus II}

Pada siklus II, pembahasan dari materinya adalah kelanjutan materi sebelumnya, yakni menyelidiki perkembangbiakan vegetatif buatan dan vegetatif alami pada tumbuhan. Proses pembelajarannya tidak berbeda dengan metode pembelajaran discovery terbimbing yakni melalui melaksanakan berbagai perbaikan sesuai dengan hasil refleksi terhadap pelaksanaan siklus I. Siswa duduk sesuai kelompoknya. Selanjutnya melakukan praktikum, sesuai materi yang sudah diterangkan, dengan peneliti memberi bimbingan hingga pembuatan kesimpulan.

Pada siklus II guru memberikan peluang untuk maju ke depan pada kelompok yang terpilih untuk melakukan presentasi terkait hasil praktikumnya. Pada saat dilaksanakan presentasi suasana belajar menjadi lebih hidup, siswa terlihat lebih bersemangat mengutarakan pendapatnya. Tindakan tersebut mampu memacu semangat belajar siswa. Berdasar pada hasil pengolahan data yang didapat persentase ketuntasan belajar siklus II meningkat dibandingkan Siklus I. Perbandingan hasil belajar kedua siklus ditunjukkan pada Tabel 2 . 
Tabel 2.

Perbandingan Hasil belajar IPA Siswa Pada Siklus I dan II

\begin{tabular}{clll}
\hline No & \multicolumn{1}{c}{ Indikator } & \multicolumn{1}{c}{ Siklus I } & \multicolumn{1}{c}{ Siklus II } \\
\hline 1 & Nilai rata-rata & 71,83 & 80,59 \\
2 & Jumlah Siswa tuntas & 29 orang & 35 orang \\
3 & Jumlah siswa tidak tuntas & 12 orang & 6 orang \\
4 & Ketuntasan Belajar & $70,73 \%$ & $85,37 \%$ \\
\hline
\end{tabular}

Berdasarkan Tabel 2, pada siklus I, ketuntasan belajar siswa sebesar $70,73 \%$ atau sejumlah 29 orang siswa sedangkan yang tidak tuntas sebesar $29,27 \%$ atau sebanyak 12 orang siswa. Sedangkan siklus II meningkat dengan ketuntasan belajar siswa sebesar $85,37 \%$ atau sebanyak 35 orang siswa sementara yang tidak tuntas hanya sejumlah 14,63\% atau hanya sebanyak 6 orang siswa. Peningkatan ketuntasan belajar pada Siklus I dan II meningkat sebesar 14,64\%. Adapun peningkatannya ditampilkan seperti pada Gambar 2.

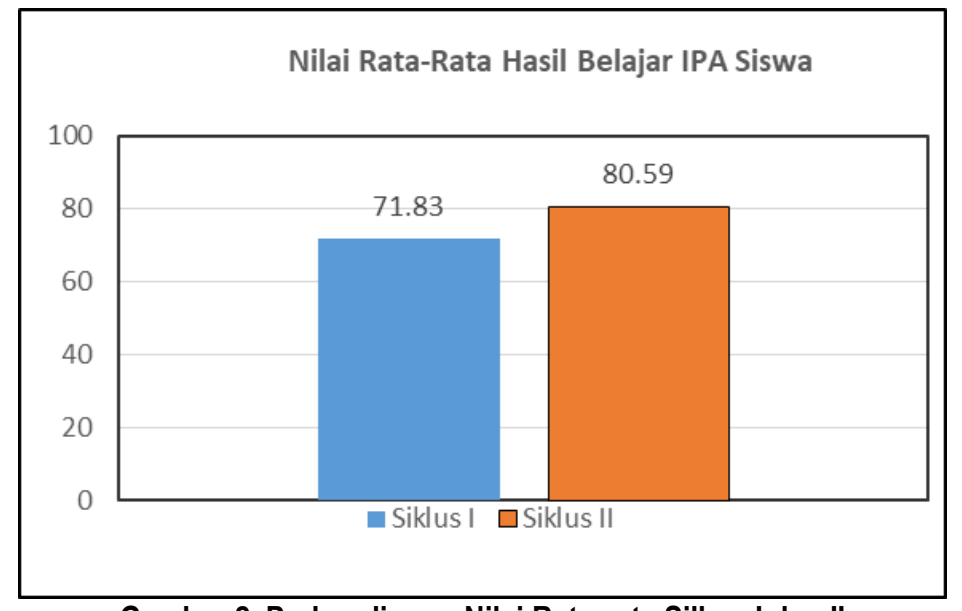

Gambar 2. Perbandingan Nilai Rata-rata Silkus I dan II

Berdasarkan data pada Gambar 2, terlihat adanya peningkatan hasil belajar siswa pada penerapan metode discovery terbimbing siklus II lebih baik dibanding siklus I. Rata-rata hasil belajar siswa pada siklus I ialah 71,83 sementara pada siklus II yakni 80,59. Peningkatan hasil belajar siswa diketahui melalui selisih nilai rata-rata kedua siklus yakni 8,76. Peningkatan persentase ketuntasan belajar siswa dari hasil observasi ditunjukkan pada Gambar 3.

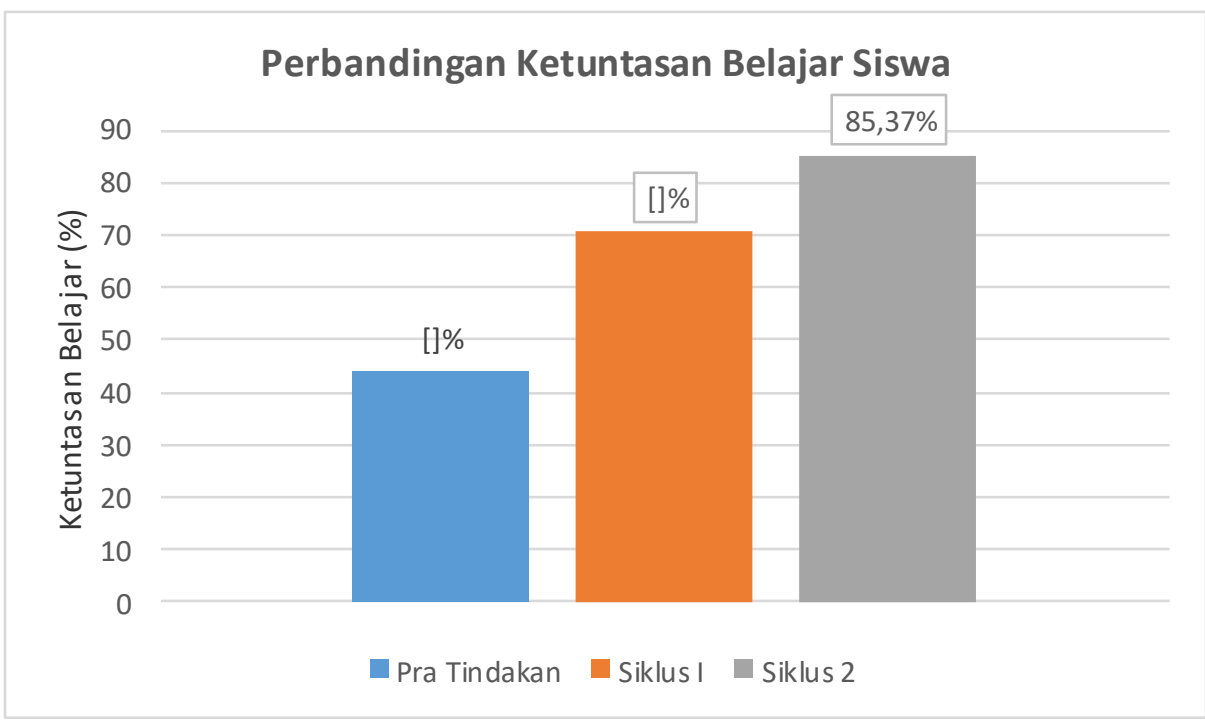

Gambar 3. Grafik Perbandingan Ketuntasan Belajar Siswa 
Berdasarkan data pada Gambar 3, persentase ketuntasan belajar siklus II sebesar 85,37\% sudah mencapai tolak ukur keberhasilan tindakan sehingga tidak diperlukan siklus lanjutan. Tindakan perbaikan pada siklus II masih tetap memanfaatkan pendekatan discovery terbimbing, akan tetapi peneliti mengelompokkan siswa dalam kelompok kecil yang heterogen baik berdasar pada kebiasaan bergaul, jenis kelamin, maupun prestasi. Uraian ini selaras akan pemaparan Slavin (Solihatin, 2009) dimana tujuan dari pengelompokan secara heterogen ialah supaya anggota kelompok bisa menularkan pengetahuannya serta bisa bekerja sama.

Pendekatan discovery terbimbing pada siklus II cenderung lebih efektif daripada siklus I sebab peneliti lebih intens dalam membimbing kelompok belajar dalam menyimpulkan serta memberi motivasi pada siswa agar melakukan persentasi sehingga dibandingkan siklus I, kegiatan siswa cenderung mengalami peningkatan. Sejalan dengan pemaparan Sanjaya (2005) dimana, discovery terbimbing berfokus kepada kegiatan siswa secara penuh, baik mental ataupun fisik. Uraian ini juga ditunjang oleh Johnson (2009) dimana memaparkan, dalam discovery terbimbing peran peneliti ialah sebagai reinforcing (fasilitator tanpa henti), yakni terus membantu siswa menemukan pengetahuan (makna).

Pada proses pembelajaran dengan pendekatan discovery terbimbing, siswa tidak hanya diberikan motivasi serta bimbingan, peneliti juga memberi penghargaan pada kelompok yang aktif. Pemberian penghargaan ini bisa meningkatkan motivasi siswa agar lebih aktif lagi dalam aktivitas kelompok misalnya perentasi dan diskusi mengerjakan soal. Kondisi ini selaras akan pemaparan Sanjaya (2005) bahwa pemberian penghargaan bisa memicu motivasi kelompok untuk melakukan presentasi serta memicu motivasi kelompok lainnya untuk meningkatkan prestasinya. Data pada siklus II telah sesuai dengan kriteria keberhasilan penelitian, oleh karenanya tidak perlu berlanjut ke siklus berikutnya.

\section{KESIMPULAN}

Penelitian siklus I menghasilkan persentase siswa dengan nilai melebihi KKM baru sebesar $70,73 \%$. Hal ini berarti kriteria keberhasilan penelitian masih belum tercapai. Pada siklus II, pengaplikasian metode pembelajaran discovery agar menunjang terhadap peningkatan hasil belajar siswa yakni dengan memberi motivasi, membagi anggota kelompok yang anggotanya lebih heterogen dan lebih kecil, serta memberi peluang untuk melakukan presentasi kelompok di depan kelas mengenai hasil praktikumnya. Pada siklus II, persentase ketuntasan belajar siswa mengalami peningkatan menjadi $85,37 \%$. Berdasarkan pada hasil penelitian serta pembahasan, bisa ditarik kesimpulan bahwa metode pembelajaran discovery terbimbing dapat meningkatkan hasil belajar IPA siswa kelas VI SD Negeri 2 Tanjung, Kota Tasikmalaya.

\section{REKOMENDASI}

Bagi peneliti lainnya yang berminat meneliti dengan pendekatan discovery terbimbing, disarankan supaya bisa meneliti lebih lanjut terkait berbagai aspek lainnya dalam pembelajaran IPA. Pendekatan discovery terbimbing dapat diteliti dengan menerapkannya pada pokok bahasan yang lainnya. Selanjutnya secara umum, mayoritas guru kelas belum mengetahui pendekatan discovery terbimbing, oleh karenanya penerapan dalam proses belajar mengajarnya masih sangat sedikit. Sekolah sebaiknya mengundang profesional yang ahli untuk memberi pelatihan kepada guru-guru kelas terkait berbagai pendekatan pembelajaran terutama pendekatan discovery terbimbing.

\section{UCAPAN TERIMAKASIH}

Terimakasih peneliti ucapkan kepada Kepala Sekolah SDN 2 Tanjung Kota Tasikmalaya yang sudah mengizinkan pelaksanaan penelitian ini serta kepada semua guru yang telah memberikan dukungan dan bantuan kepada peneliti selama melaksanakan penelitian ini sehingga penelitian berjalan lancar dan baik sesuai dengan apa yang diharapkan. 


\section{DAFTAR PUSTAKA}

Aly, A., \& Rahma, E. (1998). Ilmu Alamiah Dasar. Jakarta: Bumi Aksara.

Arikunto, S., \& Suhardjono, S. (2009). Penelitian Tindakan Kelas. Jakarta: Bumi Aksara.

Darmawani, E. (2018). Metode Ekspositori dalam Pelaksanan Bimbingan dan Konseling Klasikal. JUANG: Jurnal Wahana Konseling, 1 (2), 30-44.

Fauziana. (2019). Meningkatkan Hasil Belajar Merawat Hewan dan Tumbuhan Melalui Discovery Terbimbing Siswa Kelas II SD Swasta Pertiwi Sabang. Jurnal Ekonomi Pendidikan dan Sains, 3 (1), 7-17.

Hamdani. (2011). Strategi Belajar Mengajar. Bandung : Pustaka Setia.

Johnson, E.B. (2009). Contextual Teaching and Learning. Bandung: Mizan Learning Centre.

Marselus., Kresnadi, H., \& Salimi, A. (2018). Peningkatan Hasil Belajar IPA dengan Penemuan Terbimbing Pada Siswa Kelas 3 SD. Jurnal Pendidikan dan Pembelajaran Khatulistiwa, 7(9), $1-9$.

Sanjaya, W. (2005). Pembelajarn dalam Implementasi Kurikulum Berbasis Kompetensi. Jakarta: Kencana.

Solihatin, E. (2009). Cooperative Learning Analisis Model Pembelajaram IPS. Jakarta: Bumi Aksara.

Sutiyah. (2015). Peningkatan Hasil Belajar Siswa Kelas V Tentang Perjuangan Para Tokoh dalam Mempertahankan Kemerdekaan Melalui Pendekatan Guided Discovery Semester II SDN 2 Ngares Kecamatan Trenggalek Kabupaten Trenggalek. Jurnal Pendidikan Dasar dan Menengah (JUPEDASMEN), 1(3), 161-167. 